\section{Fructose as a Carbohydrate Constituent of Fertilizin from the Sand-dollar, Echinarachnius parma}

FERTILIZIN, the sperm-agglutinating substance derived from the jelly-coat of the egg, has been regarded as playing a significant part in the fertilization process in a variety of animals ${ }^{1,2}$. Studies ${ }^{2-4}$ of the chemical properties of fertilizin have shown that it belongs to that category of amino-acid-and sugarcontaining substances termed glycoproteins or mucopolysaccharides. Many of the constituent amino-acids and sugars have been identified ${ }^{2,5-9}$ in several species of echinoids. With regard to the carbohydrate components, galactose has been found in Strongylocentrotus purpuratus ${ }^{5,6}$ and in Echinus esculentus ${ }^{8}$, fucose in Echinocardium cordatum ${ }^{8}$, and both these sugars in $S$. draebachiensis and Paracentrotus lividus ${ }^{8}$. While not implying that sugar composition is the main basis for the specificity of the fertilizin reaction, we wish to report the presence of fructose as the main monosaccharide derived from the egg-water of the sand-dollar, Echinarachnius parma.

Both acid sea-water extracts $(p H 3 \cdot 0)$ and ordinary sea-water extracts $(p H \mathrm{H} \cdot 1)$ of the eggs of Echin. arachnius proved satisfactory for a chromatographic analysis of the sugar present in fertilizin from the eggs of this species. Egg-water, after dialysis against running tap-water, was hydrolysed in a nitrogen atmosphere for 10-18 hr. with $6 \mathrm{~N}$ hydrochloric acid and concentrated to about one-tenth volume. Ascending unidimensional chromatograms of the hydrolysates were run at room temperature. Whatman No. I filter paper was used, with the upper (butanol) layer of mixtures of $n$-butanol, glacial acetic acid, and water in the volume ratios $5: 1: 5$ and $4: 1: 5$, as the irrigating solvents. Ammoniacal silver nitrate and aniline-phthalic acid in $n$-butanol were used as developing agents, and the paper dried at $105^{\circ} \mathrm{C}$. Seven fertilizin hydrolysates were made, and all gave definite though weak spots. 'The low concentration is not surprising as the agglutination titre of the original sea-water extract was very weak. Unhydrolysed preparations and sea-water blanks gave no spots on the developed paper.

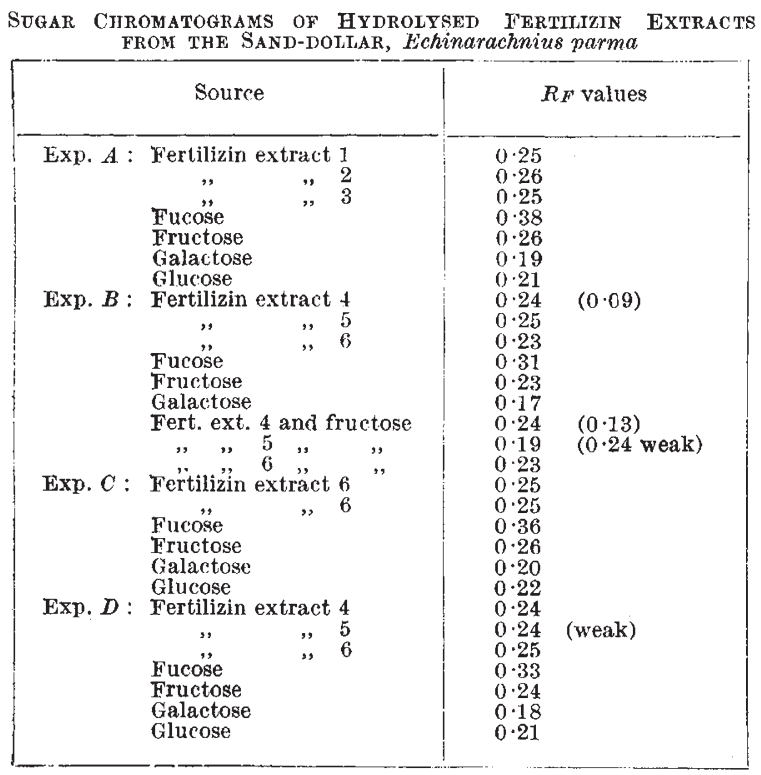

The results show that hydrolysed fertilizin gives only one spot, corresponding to the $R_{F}$ value for fructose (see table). A single spot was obtained when the fertilizin extract was added to fructose (Exp. B). In addition to fructose, one preparation (No. 4) gave another spot with a lower $R_{F}$ value, indicating incomplete hydrolysis.

\section{David W. Bishop}

CharLes B. Metz

Marine Biological Laboratory,

Woods Hole, Massachusetts. Oct. 1.

${ }^{1}$ Lillie, F. R., "Problems of Fertilization" (Univ. Chicago Press, 1919).

2 Tyler, A., Physiol Rev, 28, 180 (1948).

${ }^{3}$ Tyler, A., and Fox, S. W., Biol. Bull., 79, 153 (1940).

Runnström, J., Tiselius, A., and Vasseur, E., Ark. f. Kemi, Mineral., Geol., 15a, No. 16, 1 (1942).

${ }^{5}$ Tyler, A., Anat. Rec., 101, 658 (1948)

- Tyler, A., Amer. Nat., 83, 195 (1949).

7 Vasseur, E., Acta Chem. Scand., 2, 900 (1948).

Vasseur, E., and Immers, J., Ark. f. Kemi, 1, 39 (1949).

${ }^{9}$ Bishop, D. W., Biol. Bull., 101, 215 (1951).

\section{Occurrence of the American Pondweed, Potamogeton epihydrus Raf., in the Hebrides}

IN August 1943, when I was dragging the lochs in the vicinity of Loch Eynort in the Isle of South Uist, Outer Hebrides, for pondweeds, there occurred in a backwater of Loch Ceann a'Bagh a very puzzling Potamogeton which, in its apparently sterile inflorescence, the paucity of its floating leaves and, in some plants, their total absence, strongly recalled $\times$ Potamogeton billupsii $(=P$. coloratus $\times P$. gramineus), which I had discovered previously in Loch na Liane Moire in the neighbouring Isle of Benbecula. Nevertheless, the submersed leaves, in their general texture, lengths, breadths and parallel sides, were definitely against such an interpretation of the South Uist plant. Instead, they seemed to point clearly to a relationship with $P$. polygonifolius Pourr., or one of its hybrids. However, these ideas were in turn dispelled in 1944, when new and fruiting material was procured by Dr. W. A. Clark from a deep, peaty lochan draining into Loch Ceann a'Bagh. This enabled me to determine, with certainty, that both sets of plants belonged to the common American species Potamogeton epihydrus Raf. In this manner, not only was an important member added to the list of the American element in the British flora, but also a new species of pondweed placed on record for Europe.

Before we commenced our researches, this element was supposed to have its European headquarters in Ireland, although, so far as the Hebrides were concerned, it was recognized that Najas flexilis Rostk. et Schmidt and Spiranthes stricta (Ryd.) A. Nels. grew in the Isle of Colonsay, and Eriocaulon septangulare With. in the Isles of Skye and Coll. In the Inner Isles, our knowledge of such plants was extended in 1940 when my son Dr. J. Heslop Harrison discovered Spiranthes stricta in plenty on the Isle of Coll, and, in 1947, when I detected Juncus tenuis Willd. (undoubtedly as a genuine native) on the Isle of Tiree.

In the Outer Isles, while the presence of the freshwater sponge Heteromyenia ryderi Potts had been known for some time, the existence of the American element among the plants was first demonstrated in 1938 when I dredged Najas flexilis from Loch Altabrug in South Uist. Later, it was obtained from 